\title{
The silent but powerful communication of the physical environment of Nkozi campus of Uganda Martyrs University
}

\author{
Laura Ariko Otaala ${ }^{1}$,*
}

@Uganda Martyrs University

\begin{abstract}
The purpose of this research was to find out what Uganda Martyrs University students think about the physical environment of the Nkozi campus, which is the main campus of the university with a view to find out if that factor can be used to market the university. Two sets of examination papers (one for second year and the other for first year students) were identified from the registry archives of the university because of their relevance to the topic of research. Initially, there was no certainty about the contents of these documents, but the titles of the pieces of work were suggestive enough to qualify them for selection. The documents were analysed using thematic analysis procedures. The findings indicate that most of the students have positive things to say about the beauty of their campus. In terms of student university selection process, the information found is very useful for Uganda Martyrs University in developing a marketing strategy that can be extended as far as senior one students. Since campus visits have been found to attract many students to specific universities, Uganda Martyrs University could develop a campus visit programme in which parents, potential students and other interested persons can experience the beauty of Nkozi campus. The current students could also be used to advertise the university since they know what the university can offer apart from the beautiful campus. It is recommended that Uganda Martyrs University develop a marketing strategy that has campus visits on top of the list of strategies to be adopted in increasing student intake.
\end{abstract}

Key terms $\cdot$ University campus $\cdot$ College and University choice $\cdot$ Campus visits $•$ Marketing strategy

\section{Introduction}

Today, there are many students going for higher education than was the case previously. This seems to be happening all over the world. At the same time, there is also an increase in competition for students among higher education institutions which has led to the need to understand the processes students use to select an institution to attend or even to decide whether or not attend higher education at all. University recruitment strategies could play an important role in attracting students, thus increasing enrolment. Students can be viewed as revenue generators, a factor which is more important for private universities such as Uganda Martyrs University, since they do not receive public funding.

\footnotetext{
${ }^{1}$ Uganda Martyrs University, *lotaala@umu.ac.ug
} 
The theoretical framework for this study is based on the works of Chapman (1981) and Cabrera and La Nasa (2000). The two theoretical frameworks incorporate various aspects of the college choice process that are important for this study. Chapman's (1981) model has two domains, which affect the student's choice of a university. One of the two domains is student characteristics, which include the student's socioeconomic status while the other is external influences such as persons significant to the student, fixed college characteristics such as cost of education and college efforts to communicate with students, which includes a campus visit. According to Chapman (1981), the factors in these domains are important even before the student makes a choice of university. The campus visit is the most relevant aspect of college choice for this study since it relates with a beautiful campus, the focus of this study.

The Cabrera and La Nasa (2000) model of the college choice process has three phases or stages in which a high school student makes his/her choice. Each stage has particular cognitive and affective outcomes that together prepare high school students to make decisions pertaining to their college education. The first stage is that of predispositions where factors such as parental encouragement, support and information about college is discussed. In this stage, which is at Grades 7-9 (equivalent to Senior 1-2 in Uganda's educational system), enrolment of college bound curriculum is one of the outcomes. In the second stage (Grades 10-12 equivalent of Senior 3-4 in Uganda's system of education), parental encouragement and support is once again an important factor. The outcome here is the formulation of a tentative list of institutions where the student can apply to join and secure information about them. At the third stage (Grades 11-12) which is equivalent to Senior 5 and 6 in Uganda, educational and career aspirations become prominent even as parents provide encouragement and consider other aspects such as cost and quality of institutions. In terms of outcomes this is the stage where concrete information about expenses, institutional attributes and commitment as well as other college processes for admission come into play. What is significant about this model is that the process of college choice starts very early in the student's life. That means that institutions of higher education have to start their marketing processes early in order to capture potential students. Although this model does not mention campus visit as one of the factors to be considered, the fact that parental involvement is significant in the three stages of college choice is important because they can be involved in campus visits along with their children. If parents like the campus, they may play an important role in influencing their children in the college choice process.

This study was also motivated by other findings. The first of these is by Agrey and Lampadan (2014) who discovered that having a beautiful campus is one of the factors that affect the choice of college by prospective students. In this study, a beautiful campus was a sub-factor of the learning environment, which was one of the five major factors identified. The second motivating push for this study was the discussion of the most beautiful campuses (Forbes Lifestyle Magazine, 2007). In this source, most of the beautiful campuses found their beauty in nature (the greenery and associated 
features), while a smaller number of campuses had their beauty linked to buildings of special architectural forms. The third motivator was on the importance of a campus visit in the selection of colleges and universities. The fourth was the importance of a campus in the life of a university. In this regard, the University of Colorado Campus (Springs Design Guidelines, 2007) says it all:

A campus is the mirror of a college or university's soul, reflecting its history, its culture and image, its management style, and even its future. It tells all who visit it how it thinks about itself and the way it expects others to judge it.

The fifth motivator was the health benefits that have been found to accrue from nature (Maller et al., 2005). Although this study is not about the health benefits of nature, but people can benefit from such an environment by appreciating one's place of abode. With this, I set about highlighting one feature of the soul of the Nkozi Main campus of Uganda Martyrs University, the physical environment. I chose to focus on this aspect of the university because of the outstanding beauty of this particular campus. The university has other campuses, including Lubaga, which is located in Kampala; Mbale, in the Eastern part of the country; Masaka, in the South-West of Kampala and Kabale, in the Western region of the country. Although all the campuses have their own admirable features, Nkozi campus has received the most positive comments from visitors. One such visitor was a Government minister who was officiating at one of Uganda Martyrs University graduation ceremonies as a guest speaker. In his speech, he said:

Thank you for inviting me to Uganda Martyrs University on this important occasion. I am always very happy to come to this campus because of its beauty. I don't know how you manage to always keep it so green.

Another comment, which I heard myself, came from a sibling of one of the first year students reporting to campus on the first day. She said to her sister, "This campus is so green and breathtaking. You can never run short of oxygen here." This sibling seems to have remembered her science lessons. I was also motivated to find out what students, the main customers of the university, think about the campus. The focus was on those who are residents of the Nkozi campus since they live in this environment. The students who are already on campus may not have considered a beautiful campus as a factor influencing their choice to join Uganda Martyrs University, and they may not have visited the Nkozi campus before making their application, but I believe that what they say can influence future potential students. What they say to family and friends has an impact on their decisions for siblings and others. One can also not ignore the possibility that some of these students may have had conversations with past students of Uganda Martyrs University who either lived in Nkozi campus or 
visited the campus from the other campuses. There is yet another possibility that parents and other visitors to the campus may have mentioned something about the beauty of Nkozi campus to other parents or potential students. The information gained from this study can also be used by the university to market itself through other means.

Although the research did not set out to find all the factors that influence students' choices of universities, it focuses only on one of the factors that has been identified in the literature, which is the campus visit (Chapman, 1981; Hossler and Gallagher, 1987). The major thesis of this article is that a beautiful campus fits in well with the campus visit, which is one of the factors that are influential in students' selection of university. Investigating the importance of a beautiful campus contributes to the knowledge about the students' decision-making process. This factor may not be directly relevant to current students who have already made their choice, but it can contribute to the university selection process of those students who may be considering which university to choose. Within the campus visit lie factors such as aesthetics of the campus environment, community vibe of the campus, and personal interactions (Okerson, 2016). This article adopts the view that if students have a lot to say about a particular aspect of their stay in a university, that aspect must be important to them. This is further elaborated upon in the section on methodology where it is explained that the information was not specifically solicited from the students, but came out as part of another academic exercise.

\section{Research questions}

The following are the research questions that the study set to answer:

1. What do Uganda Martyrs University Students say about the physical environment of Nkozi campus?

2. What effect does the physical environment of the campus have on the students?

3. What are the implications of campus environment perceptions for the university marketing strategy?

\section{Literature review}

Many studies on the factors that affect students' choice of university have been carried out. Hoyt and Brown's (2003) review of 22 studies identifies nine factors that fall in the number one category across several studies as academic reputation, location, quality of instruction, availability of programmes, quality of faculty, costs, reputable programmes, financial aid, and job outcomes. The next most important factors across the 22 studies, according to the review are variety of courses offered, size of the institution, surrounding community, availability of graduate programmes, student employment opportunities, quality of social life, class size, admission to graduate 
school, extracurricular programmes, friendly personal service, affiliation (with another reputable institution), admission requirements, and attractiveness of campus facilities. There is no mention of the campus visit or attractiveness of the campus as one of the criteria for university choice. This may be because some of the factors did not meet the criteria set for the review by the reviewers. Indeed, the reviewers recommend that in-house instruments by universities could yield useful information that can supplement the national data sets used by many researchers. Other studies have identified "university environment" (Fosu and Poku, 2014) without telling the reader what falls under this environment. It could include campus aesthetics, which is the concern of this article. There is, however, research that has found the campus visit an important factor in the choice of universities. The campus visit has been found to be a major factor in the decision-making process (Servier, 1992) while Noel-Levitz (2009) found the campus visit as the most important influencing factor in a student's decision to enrol in a university. This factor along with others led Ming (2010) to develop a conceptual framework of college choice decision made up of fixed college characteristics which includes location, academic programmes, college reputation, educational facilities, cost, availability of financial aid and employment opportunities and college effort to communicate with students covering advertising, higher education institution's representatives and campus visit. Other researchers who found the campus visit to the most influential factor affecting university choice include Hayes (2014) and Robertson et al. (2017) who found that the campus tour and visiting with a faculty member on campus are the most influential over all other recruiting strategies in the student's decision to enrol at a particular university. Perhaps the most dramatic proponent of the campus visit is Hesel who has this to say:

In my 25-plus years as a consultant in higher education, and in the course of innumerable recruitment studies conducted for colleges and universities of every size, affiliation and mission over the years, one finding has remained constant: the campus visit is the single most influential source of information for students in college choice. While web sites now surpass publications as a source of influence over the college decisions of prospective students, the campus visit stands in a category all [of] its own $(2004$, p.1)

Although the campus visit is important in the students' decision-making process, it is also important to understand what aspects of the visit are influential. Some of these are the campus tour and visiting with a faculty member on campus (Robertson et al., 2017); aesthetics of the campus environment, community/general vibe of campus and personal interactions (Okerson, 2016); personalised attention, a welcoming tour guide, and campus tour stops (Spoon, 2006). What is important is for the potential students to visualise themselves as current students on campus (Spoon, 2006) and to experience what looks like a college (Okerson, 2016). 
It is clear from the above literature that the campus visit is an important factor of college choice. This strategy of recruitment has several advantages one of them being that it is a revenue generator because the more students a university recruits the better its financial status. Another advantage is that it is the least expensive to employ (Robertson et al., 2017). An associated advantage is that the institution can sell promotional material such as caps, key chains and pens, which are cheap to produce and easy to sell if properly handled. This brings more revenue to the institution especially if the campus visit attracts a big number of visitors. For a university like Uganda Martyrs, which does not have campus visits, it could be something to consider investing in. This research is a good start in this process. It starts with establishing the viability of such an approach to recruitment by finding out what students of the university think of its campus environment, which constitutes the aesthetics of the campus environment.

Closely related to the campus visit, in the choice of a university, is the importance of external influences, which includes parents, friends and high school personnel (Chapman, 1981). Others entail siblings, friends, teachers and other people who play an important role in the student's life (Kusumawati, Yanamandram and Perera (2010); Pimpa (2005). Peers are influential because they are part of a social group that support each other. Family in general are important because they provide financial support, help in the search for information about universities, extend their expectations to the student, and generally play a persuading role in the choice process. In cases of private institutions, the family may bear all the costs of having a student at university. Family financial support may limit the student's choice to study in certain institutions or even programmes (Kusumawati, Yanamandram and Pereira (2010). Family influence has been found to be a major factor in the selection of higher education institutions (Shanka, Quintal and Taylor, 2005). In terms of this article, a campus visit by either the potential student of a university or the significant people in his/her life may provide a positive or negative image of a university, in turn, will influence the candidate's decision. A beautiful campus will most likely affect the candidate's choice positively as he/she examines the other attributes of the potential university.

The focus of this study - the physical environment - has not been highlighted in many of the studies dealing with college and university choice. In this paper, the physical environment is taken to include factors such as the attractiveness/beauty of the university campus. The environment is part of the campus visit, which is one of the factors that influence prospective students in their choice of a university. This can include the compound and buildings. One study that has specifically identified attractiveness of the university campus is Catley (2004), which also includes attractiveness of the city in which the university is situated as an important influencing factor, in that, more students were drawn to this particular university because of the city's attractiveness. This is important for this research if it is discovered that there is a feature of Uganda Martyrs University that could draw students to it, then this would 
help the university to plan its marketing strategy using this feature as one of the bases of its campaign to attract more students.

The concept 'campus' is important in campus visits. Researchers and practitioners have found that campus visits are important in the students' plans to apply to an institution and to matriculate (Campbell, 1977; Dembowski, 1980; King, Kobayashi and Bigler, 1986; Yost and Tucker, 1995; Sevier, 2000; and Fischbach, 2006). Campus visits have been found to be the most influential and trusted sources of information for prospective students (Hesel, 2004; Ashburn 2007; Cohen, 2009). Colleges and universities can encourage campus visits as a recruitment tool because it has been found to be a powerful factor in student college choice (Kellaris and Kellaris, 1988). In order for campus visits to be worthwhile for parents and potential students, the colleges and universities have to work on improving those features of the campuses that can give first impressions. These features include routes to the campus, appearance of the campus gateways and grounds, availability of parking space for visitors' vehicles, overall cleanliness of the campus, and appearance of the office and staff greeting visitors (Klein, 2004).

A beautiful campus can be recognised by either its buildings or the natural environment within or surrounding it. Forbes Lifestyle magazine (2007) says that although campuses should not be candidates on a beauty contest, prospective students have consistently cited campus aesthetics as a school choice consideration. Using a group of architects and campus experts as judges of American colleges and universities, Forbes magazine found that more than half the institutions that made it to the top got the slots because of the natural beauty while some made the scale through specific architectural buildings such as chapels. Some others had a combination of natural features such as lush green grass, tall trees and other aesthetics. That means that paying attention to nature is important for universities. As far as health benefits of natural environments are concerned it has been found that personal health and wellbeing can be restored through significant interaction with nature (Maller et al., 2005; Abraham, Sommerhalder, and Abel, 2010). That means that students who are in a campus with attractive lush green grass, flowers, trees and other components that constitute nature's beauty can be said to have the advantage of good health naturally.

Students also seek advice from other interpersonal sources such as friends, siblings, counsellors, career advisers, former professors, former/current university students and word of mouth from different people (Murphy 1981; Shanka, Quintal, and Taylor, 2005; Briggs and Wilson, 2007). Current students of Uganda Martyrs University could greatly influence potential students by using their own experience of the Nkozi campus. Catley (2004) also found that personal recommendations that the students had received from sources such as friends, family, school and the career guidance, influenced the students' choices. Therefore, a beautiful campus, which can be used as a tool to sell the university to potential students, plays a big role in campus visits, if they are introduced by Uganda Martyrs University. Currently, there is no such 
programme at Uganda Martyrs University. Maybe the knowledge acquired in this research may motivate the university to introduce such a programme.

\section{Methodology}

The data used for this article were secondary data obtained from the Registry Archives of Uganda Martyrs University. They consisted of previous examination papers. There were two sets of examinations chosen for analysis because of their relevance to the topic. One was an examination set for second year students taking Original and Critical Language Skills as one of their course units. For the free writing section of this examination paper, these students had the following question:

Write four (4) journal entries of a reflective journal on one of the following topics:

1. My Primary and/or Secondary school life experiences

2. My two years at Uganda Martyrs University.

Forty students answered Question 2. These texts were analysed because of their relevance to the research questions for this article.

The second set of data were collected from the Essay writing section of the Proficiency Test given to the first year students at the end of their orientation week. For this section of the test, students were given the question below.

Write a 250-word essay on one of the following topics:

1. My impressions of Uganda Martyrs University so far.

2. The importance of university education.

In this test, 58 students chose Question 1. Since this was of relevance to the research questions, these 58 essays were analysed. I am aware of the fact that the students may do their best to write about what they think will get them high marks. This could be looked at as part of the Hawthorne effect, which says that people change behaviour under participation in research (Wickström and Bendix, 2000). Cambridge, Witton, and Elbourne's (2014) review of relevant literature shows that all the 19 studies reviewed except one have been undertaken under health sciences, which means that in many disciplines this effect, if it exists, may not be applied in all disciplines. Additionally, there are controversies and inconsistencies in the findings with regard to content and strength of the effect (Cambridge, Witton, and Elbourne, 2014). The reviewers' conclusion is that there was no one single Hawthorne effect. For this study, there are other comments by visitors to the Nkozi campus (indicated elsewhere in this article), which suggests that the students under consideration are telling the truth.

In total, there were 98 written pieces of work analysed. The approach adopted was thematic analysis (Braun and Clarke, 2006) which used an inductive approach to the establishment of themes as they emerged. The 6-step process involves becoming 
familiar with the data, generating initial codes, searching for themes, reviewing themes, defining themes and writing the findings. The students who wrote the Reflective Journal are indicated using [RJ] as a form of identity, while those who wrote the Proficiency Essay are shown as [PE]. The number of students for each genre is shown in Table 1 below.

Table 1: The Number of students who chose each of the questions given

\begin{tabular}{lc}
\hline Topic & Number \\
\hline My two years at Uganda Martyrs University & 40 \\
My first impressions of Uganda Martyrs University & 58 \\
\hline
\end{tabular}

Source: Field data, 2018

There were several themes identified in the reflective journals and proficiency essays. For the purposes of this article, only those that related to the physical environment were discussed in order to find out how students felt about the Nkozi campus. It should be noted here that when students refer to 'the university' they are actually writing about the Nkozi campus because those students who came to the Nkozi campus write all the documents analysed. The choice of first and second years indicates whether students care about the environment in which they find themselves. The first years are new and if they say something positive or negative about the physical environment of Nkozi campus, it will indicate their inclination towards this feature of the campus. For the second years, the writing involved looking back at their experience from the first year. If there is something said about the environment it will indicate that they were and may still be impressed with it positively or negatively. Since the responses to the questions were not specifically focused on the physical environment, if there is any reference to this feature at all, it will constitute an unsolicited reaction, which can be taken to mean that the physical environment must mean something to the students.

\section{Findings and discussion}

To answer the first research question, the first step taken was to find out how many students mentioned anything related to the physical environment. The findings are indicated below.

\section{The physical environment as part of the Nkozi campus}

From the analysis of the students' journals and essays, it was found out that 13 students who wrote the RJs and 33 students who wrote the PEs mentioned the word 'environment' in their writing. Some other students ( 6 for RJ and 6 for PE) used 
'compound' in their writing. Others used 'place' (1), 'campus' (2) and 'physical appearance' (1). This is shown in Table 2 below.

Table 2: The words used for the physical environment of Nkozi campus

\begin{tabular}{llc}
\hline Word & & Frequency \\
\hline Environment & (RJ) & 13 \\
& (PE) & 33 \\
Compound & (RJ) & 06 \\
& (PE) & 06 \\
Place & (RJ) & 01 \\
& (PE) & 00 \\
Campus & (RJ) & 01 \\
& (PE) & 01 \\
\hline
\end{tabular}

NOTE: RJ= Reflective Journal, $\mathrm{PE}=$ Proficiency Essay

Source: Field data, 2018

\section{Description of the environment}

While the data above shows that the environment seems to be in many of the minds and hearts of both the first and second years, it is important to find out whether the students have a positive or negative feeling about the Nkozi Campus physical environment. The findings indicate that there is a generally positive feeling about the environment as seen below. I believe these students were free to say whatever they wanted because, first, they were free to choose whichever question they felt comfortable with. Second, I have given other assignments in class and out of class where students expressed themselves freely. This may be because a culture of vindictiveness on the part of lecturers at Uganda Martyrs University is discouraged as far as I am able to judge. The language the students use to describe different aspects of the physical environment is divided into categories of focus, which are shown in the sections below. In other words, this section answers the question, 'What was striking to the students about the campus?' As is common with this kind of free writing, there were other themes mentioned in the same sentence or paragraph. I simply tried to find the major theme and others were discussed as they occurred.

\section{The beauty}

One of the striking things that the students noticed about the Nkozi Campus is its general beauty. This is described using the noun 'beauty' or the adjective 'beautiful'. We see the use of the noun form below.

RJ18: Finally, we reached our destination and that was Uganda Martyrs University. Upon reaching, I was astonished by the beauty of the place. 
RJ21: I set off to Mpigi district, Nkozi village where Uganda Martyrs University main campus is located. On our way, I looked outside and was amazed by the beauty of green vegetation. "Well... this will be my home for the next three years", I whispered to myself.

RJ25: I was fascinated with the beauty of the university as a whole, that is, the compound and the people who were so welcoming, so I felt at home there and then.

PE2: My eyes opened to view the beauty of Uganda Martyrs University, which looked like heaven on earth.

PE10: Far from the city, up the hill of Nkozi amidst tall green trees lies a beauty untold. The breeze picks you from the first landing on the neighbourhood. The calm environment coupled with well-planned green land, walkways and structures is the brief of Uganda Martyrs University, Nkozi.

I have separated "beauty" from other themes within the students' expressions of what they saw because the students used the word "beauty" in their own utterances in contrast to other themes, which add to the beauty of the Nkozi campus. Other aspects of the environment are also described below. For those who chose to use the adjective form 'beautiful', we have some examples shown below:

PE12: The first time I entered the gates of Uganda Martyrs University, I knew my dreams were going to become true following the Askari's direction to the parking yard, gazing at the beautiful, cool environment of the university. I was impressed deep down in my heart.

PE19: It is one of those things that I have been eager to watch, share and experience as a teenager even before I became fully and wholly part and one of the very few in this beautiful environment.

PE25: The environment is wonderful, eye-catching that can make one feel proud of being here. It is beautiful. It is truly a place worth staying at.

PE41: Well, as everyone says, 'It's so far from the central [Kampala city], nothing seems interesting as in its way hidden from fun', but this did not seem the same when I got there. I saw a very beautiful conducive and peaceful environment and this made me smile like a little child who has been bought a box of sweets. "Wow, it was an amazing scenery; the flowers, buildings, they look like historical buildings!

As can be seen above, the students describe their feelings and reactions to the beauty of the campus in different ways. Some were "astonished" (RJ18), "fascinated" (RJ25), and "amazed" (RJ21) or saw an "amazing" scenery (PE41). The environment 
is also described as "wonderful" and "eye-catching" (PE25) and this makes the campus "a place worth staying at" for this student. Some "gazed" at the beautiful campus, which suggests that some took time to admire the beauty. It was not just a glance. What contributed to the beauty for these students was the "green vegetation" (RJ21), the "tall green trees", the breeze, the "conducive and peaceful environment" (PE41), the "flowers" and "historical buildings" (PE 41). It is not possible to be sure what the word "conducive" (PE41) refers to, but one could speculate. Perhaps the campus is conducive to learning as is suggested by other students in later sections of this article or conducive to relaxation as often happens. It should also be noted here that the feelings about this beauty are not just surface feelings. For one student who was "impressed deep in my heart", the depth of the feeling is suggested (PE12).

We also see the effect of the beautiful campus on the students in that some are certain they will complete their programme at the university (RJ21) while another student "felt at home there and then" on perceiving the campus (RJ25), again confirming that the student will stay for the long haul. The effect of the environment is also seen in the way it made another student "smile like a child who has been bought a box of sweets", which indicates joy, happiness, comfort and satisfaction (PE41), while another student felt that the campus was "a place worth staying at" (PE25). There is what appears to be exaggeration here since the writing is a creative exercise. However, if we peel off the "overcoat" we can still see the plain beauty of the inner cover. All these feelings are consonant with the motto of Uganda Martyrs University, which says that the university is "a place where it is good to be". Certainly, this one aspect confirms a good environment attracts people and makes them want to be in it.

\section{The greenness of the environment}

The attractiveness of a place can be found in the buildings, the roads, and the natural environment. Nkozi campus seems to have plenty of greenery that impressed the students upon their arrival. The greenery seems to have been more overwhelming than the other aspects of the environment. We explore students' feelings on this greenery below.

RJ30: I joined the university not having an idea about it but after seeing the university, the compound impressed me to love the university. Uganda Martyrs University is an institution located in Nkozi along Masaka road, and has a very attractive and green in nature environment.

RJ35: You can never appreciate nature until you see the green in the Nkozi compound. All the 'keep off the grass' signs are all there to help remind you of the importance of the environment.

RJ37: When I reached the place it was so quiet, organised and too green. I knew it was meant for me. 
PE22: Uganda Martyrs University is a university that has a very beautiful compound with green vegetation all over and limited noise. This makes it so conducive for studying.

RJ14: When we reached the campus, I was overjoyed and mesmerised by the green and beautiful compound, which made me say to myself that, "this is the place to be".

The above students were particularly moved by the greenness of the campus. How they felt is indicated by the different expressions. On seeing the greenness of the campus, one student suggested that you have to see it to believe it (RJ35). RJ14 was "overjoyed and mesmerised" by the green and beautiful compound. This speaks to the power of this natural environment to hold people's attention. Another student was moved to "love the university" just by the greenness which also made the compound "attractive" (RJ30). This is an advantage to the university in that students can get to love it even if they have not been to the place before because those students are not likely to leave the university before completing their programmes. RJ35 recognises that the greenness of the compound does not just happen. People have to work together to maintain it, that is, by observing the "keep off the grass" signs that are placed around the compound. To complement the greenness of the compound, there is also "limited noise" (PE22) and the "quiet" atmosphere (RJ37). PE22 indicates that the compound is not just dotted with green vegetation but has this green vegetation "all over", thus suggesting vastness of this feature. The same student seems to believe that this kind of environment is "conducive to studying", which gives the impression that the university meets academic standards as well as other requirements. The comment "I knew it was meant for me" shows how much the beauty of the green at Nkozi campus communicates to people individually. We also see the joy that the green compound gives the students when one says, "I am really enjoying my stay at Uganda Martyrs University..." The literature on campus visits and tours does not give as much detail as is found here. Things that are considered important have been mentioned in the introduction and literature review. Apart from the Forbes Lifestyle Magazine (2007), whose focus is the ranking of universities in the United States in terms of their beauty, other researches give general features of a campus visit and what is important during the visit. For Uganda Martyrs University, the beauty of Nkozi campus can be a powerful tool in the recruitment process. Good planning can produce great results.

\section{The abundance of grass, trees and flowers}

This section is separated from the one on greenery because there is specificity about the things that seem to matter to the students. In addition, flowers also are part of things that make Nkozi campus beautiful. These flowers may be of different colours other than green and that is part of the reasons for the need to have this section. We 
see the effect of features (trees, grass and flowers) on the students in the examples below.

RJ26: I felt somehow helpless so I sat down for a while and eventually manning up some courage, I descended into the compound and I spent the rest of the evening admiring its nature, which was littered with flowers, paved walkways, with beautiful green grass.

RJ38: As we went outside the auditorium we were given different ushers to make us tour around the campus but what I saw I seemed to be seeing heaven on earth, I saw a beautiful compound full of flowers, trees, and green grass. I was amazed, not regretting why I had chosen this university. I was like wow! What a good environment to live in.

RJ39: At around $4.07 \mathrm{pm} \mathrm{I}$ arrived at the university gate safely. The environment was so calm, trees and flowers everywhere one could understand that the place is so overwhelming and comfortable.

There is also appreciation for the green grass found at Nkozi campus in addition to "flowers" (RJ26, RJ38 and RJ39) as well as "trees" (RJ38, RJ39). There is also a suggestion that there is an abundance of flowers from the use of the words "littered" (RJ26) and "everywhere" (RJ39). In addition to the things which nature provides, there are also fabricated "paved walkways" (RJ26), which suggests that at Nkozi, man has worked with nature to provide a beautiful environment. The exclamation "wow!" (RJ38) shows amazement at the view of the compound while the place is also described as "overwhelming and comfortable" (RJ39) - both powerful emotions. The good environment is not just good for visitors to see, but it is a good environment "to live in" (RJ38). The student here has settled in. There are also no regrets about having chosen Uganda Martyrs University (RJ38), again confirming the potential retention of students once they have enrolled at the university. The emotions of the students about what they saw are again expressed powerfully in the statements "I was really amazed", "... I seemed to be seeing heaven on earth" (RJ38). We also see that the campus is so attractive that one student "...spent the rest of the evening admiring its nature..." (RJ26). There is a lot of poetic language in the students' descriptions. Visitors, too, as indicated elsewhere in this article, have marvelled at the ever-beautiful campus.

\section{The abundance of birds and other living things}

Because of the greenness of the natural environment, birds and other living things have populated the campus. Students seem to appreciate the presence of these creatures. We see this in the extracts below. 
RJ22: I fully enjoyed the moment and ambience around my hall of residence. The beautiful green, the birds chirping felt like music in my ears. Then there was the look of the sun setting that day with nice fresh breath of the place, nature, which was so nice while I sat at the relaxation place while I admired the beautiful scenery of God's creation with a great feeling of being at the most nice and gorgeous university in Uganda.

PE37: First, I am excited about the beautiful compound decorated with various trees and flowers around with nice aroma and the many birds, which sing sweet melodies at the botanicals.

PE40: On my long awaited journey to seek success, was my dream to receive education at Uganda Martyrs University. I felt respect and it being quiet made it a place of nature, birds and other livings things, which live within it. This even made my room a prayers room to pray to God to dwell in us and fill us with the Holy Spirit.

In addition to the beautiful green environment, a few new ideas are introduced here. There are birds whose chirping "felt like music in my ears" (RJ22) or "sing sweet melodies at the botanicals" (PE37). Here the melodies drew the attention of the students. The use of the word "botanicals" suggests large green gardens for scientific study. PE40 appreciates the "birds and other living things that live within it", meaning the beautiful environment. Since the campus is "a place of nature", it invokes spirituality in some students as the rooms can be made places of praying to God (PE40). The use of the word "decorated" (PE37) suggests either human effort or God's gift since there are times when the beauty of a place makes one feel like it is decorated. Of course, humans can work with God in many respects to create beauty as well as other things. When a student feels "respect" for the beauty of the environment (PE40) we can see the importance of this environment to the student. In this section, we also see something new about the flowers - the "nice aroma" created by the flowers. It is not just the look (sense of sight) but also something for the nose (sense of smell) that attracts one's attention. There is also a freshness of the air that is brought out in RJ22. The total effect of these features creates a sense of landscape where health can be restored, stress reduced and general well-being can be facilitated (Abraham, Sommerhalder and Abel, 2010). Some readers of this article might think that the language used by students here is an exaggeration but I believe that beneath this "flowery" language lie core features that are important for the students. One could say, for example, that the Nkozi campus is inhabited by singing birds, other living creatures and sweet-smelling flowers. That is the core message here. Again, this is not a feature that has been focused on in the literature cited.

A comparison with other universities in Uganda is also introduced in RJ22 since Uganda Martyrs is "the most nice and gorgeous university in Uganda". This assumes the student has been to all the universities in Uganda. Even if he/she has not done so, the feeling must have been strong enough for him/her to make that claim. 
Alternatively, he/she may have friends, siblings and other contacts in several other universities from whom he/she gets a picture of how those institutions look like. In today's world of technology, it is even possible to share pictures of the other universities with others from distant areas.

The feeling of the students is also seen here. In RJ22, the student "fully enjoyed the moment and ambience...)." The use of the adverb "fully" emphasises the enjoyment. Another student was "excited" about the beautiful compound, which shows an arousal of feelings beyond the lukewarm.

\section{The cleanliness}

The students were also astounded by the level of cleanliness of the Nkozi campus. This is what some of them had to say:

RJ24: I was walking through the university in total awe and amazement. It was such a beautiful sight and very clean and organised. It was at this point that I knew I had made the right choice.

PE8: For the five days I have spent at Uganda Martyrs University, I have been impressed by the desirable campus environment, which is clean, plus the halls of accommodation with all the needed facilities.

PE27: On my arrival, many things caught my eye starting with the clean environment and welcoming young men and women.

PE28: One of the things that impressed me was the cleaners that keep the environment very clean every single day and it is a very quiet place with a cool situation.

PE35: The infrastructure is good and the compound is always clean.

PE44: The second was the beautiful compound compared to other universities. The compound is ever clean, no dust within the campus and the rooms we are staying in are very good.

PE47: Furthermore, the university is a good place to stay with a good environment full of quality property and a clean environment

PE48: The first impression I got from the university was the general cleanliness right from the campus gate, compound up to the toilets. I was also impressed with the beauty of art of the school design, that is to say, the school compound, buildings.

All the above observations indicate that the Nkozi campus is "clean" (PE8, PE47); "very clean" (RJ24, PE28); "always clean" (PE35); "ever clean" (PE44). PE44 adds 
that there is "no dust" in this clean environment. In PE48, one is shown how far this cleanness goes: "right from the campus gate, compound up to the toilets". The cleanness is not an isolated thing being witnessed only in some sections of the campus. There is also a comparison of the campus to an "art" piece, which goes along with the design of the buildings (PE48). The environment of the campus is also "full of quality property", which suggests that the buildings and other aspects of the campus together constitute good property. Students also recognised the quietness and coolness of the campus (PE28) and the organised nature of the campus (RJ24). The recurrence of references to the cleanliness of Nkozi campus cannot be said to be an attempt by a student to get high marks. If it were only one or two students mentioning this fact, one would be tempted to say that this is the case. In the literature cited above, there is no mention of this feature. This seems to be a unique feature of the campus, which could be used in a programmed campus visit. Just giving potential students and their parents a guided walk through the campus would surely reveal this unique feature. One student noted that the beautiful compound of the Nkozi campus was impressive "compared to other universities" (PE44).

In terms of feelings which were evoked by the environment, one student reports that $\mathrm{s} / \mathrm{he}$ "was impressed" by the beauty of the school (PE48) while another walked through the university "in total awe and amazement" at the beautiful sight (RJ24). One student also felt s/he "had made the right choice" by joining Uganda Martyrs University which means that her dreams had been met. These are expressions of students who may not have had the idea of a beautiful campus as an influential factor but now that they are here, they appreciate this environment and will, most likely recommend the university to potential applicants as a choice destination. The student can be part of a peer group helping each other to make the right choices (Pimpa, 2005).

\section{The fresh air}

The importance of fresh air is seen in the extracts below. Natural environments are usually associated with fresh air. Students in the study have positive things to say about this relationship as is seen below:

PE14: Its buildings are well organised with strong foundations and the environments neatly taken care of with fresh air that keeps one's lungs fuelled immaculately.

PE18: It was around noon when I was welcomed by the beautiful sceneries of the green grass and trees. This created fresh air and I knew this environment would be the best for my university education.

PE43: Monday $18^{\text {th }}$ August 2015 was the first day I stepped my foot in this adorable university. I was as happy as a queen was because it was 
always my dream to join campus. The air, which was fresh and made the tree leaves to dance to its tunes made me feel more comfortable with the place. The campus was as silent as a grave. I really confirmed that my choice was the best because all the first conditions could be a good way to my academic excellence.

PE45: The University is so clean, quiet and lots of trees. The fresh air surrounds the buildings in the school.

In this section we see that fresh air "keeps one's lungs fuelled immaculately" (PE14) and the fresh air makes the student believe that "this environment would be the best for my university education" (PE18). The fresh air also "made the tree leaves to dance to its tunes made me feel more comfortable with the place" (PE43). There is a sense of poetry in this statement, which can only come when one's emotions are aroused. Here there is beauty, joy and comfort. Since fresh air is usually found in natural and clean environments one can say that it is part of human health benefits that people get when in contact with nature (Maller et al., 2005). In terms of university choice, those students who are residents of Nkozi campus can concretely recommend the university to those who are in the process of choosing a university. They may not talk of health in medical terms, but they can talk about breathing fresh air and the associated health benefits.

The second research question has also been answered in the process of answering the first question. In the students' responses, the effect of the environment was revealed. The general effect was that of appreciation of the environment. Quite a number of students felt that they had made the right choice in joining Uganda Martyrs University.

To answer the third research question, one can start from the answer to the second question. The students showed appreciation of the environment of their campus. The implication of this is that they will let other people know about the beauty of the Nkozi campus. This is particularly important for young students in high school who are still searching for what to do, where, and when their studies at that level are completed. Such students may be family members, friends or social contacts. The university can also make use of the information from this study to develop a marketing strategy to attract more students for enrolment onto its programmes/courses.

\section{Conclusions and recommendations}

The theoretical frameworks that have informed this study suggest that the campus visit is an important factor in university choice. A beautiful campus fits into this framework because it is a sub-theme within the campus visit that should be given more importance than it has currently in many studies of university choice. Arising from the findings is the fact that Uganda Martyrs University has a unique property, a beautiful campus, which it can use, along with other factors found in the literature to develop a 
campus visit programme to attract more students to the university. Since Cabrera and La Nasa's (2000) frameworks indicate an early start in students' lives, Uganda Martyrs University should develop a programme that can be used at all levels of high school. Starting to interest students in the university as early as Senior 1 would ensure that by the time students start filling application forms they are sure of where they want to go for higher education. In terms of factors influencing students in the selection of colleges and universities, one can say that the Nkozi campus of Uganda Martyrs University has a lot it can use to market the university. The students who are already on the ground can be used to pass the message to prospective students and their parents or guardians; by convincing them that Uganda Martyrs University is a good choice. The main campus is beautiful; it has a lot of green grass and tall trees, flowers and creatures such as birds living within that environment. There are pavedconcrete pathways, which are safe to walk on and keep the residents and visitors from getting dirty. The compound, as well as the buildings, are immaculately kept. There is plenty of space and fresh air, which are conducive to good health. The learning environment is peaceful, attractive, quiet, clean, and provides students with a home away from home. Compared to other universities, Uganda Martyrs University is lucky to have a campus that is as beautiful as Nkozi. The students on the ground rank the campus top of the Ugandan universities with regard to the beauty of the compound and they provide evidence for this ranking. This ranking is their own, not national or international ranking, but if it works for them then it can be used either alone or in relation to the other types of rankings.

\section{References}

Abraham, A., Sommerhalder, K., and Abel, T., 2010. Landscape and well-being: A scoping study on the health -promoting impact of outdoor environments. International Journal of Public Health, 55:59-69

Agrey, L. and Lampadan, N. 2014. Determinant factors contributing to student choice in selecting a university. Journal of Education and Human Development, Vol. 3(2): 391-404.

Alhojailan, M. I., 2012. Thematic analysis: A critical review of its process and evaluation. West East Journal of Social Sciences, Vol. 1(1): 39-47

Ashburn, E., 2007. Prospective students reply on campus visits and web sites to learn about colleges, report says. The Chronicle of Higher Education, Vol. 53(38): p, 39

Basko, A., 2008. How improving campus visits increased applications at Franklin \& Marshall College. Recruitment \& Retention in Higher Education, Vol. 22(6): 4-5.

Braun, V. and Clarke, V. 2006. Using thematic analysis in psychology. Qualitative Research in Psychology, Vol. 3: 77-101.

Briggs, S., and Wison, A., 2007. Which university? A study of the influence of cost and information factors on Scottish undergraduate choice. Journal of Higher Education Policy and Management, Vol. 29(1): 57-72. 
Cabrera, A. F. and La Nasa, S. M. 2000. Understanding the college-choice process. New Directions for Institutional Research, 107: 5-22.

Cambridge, J., Witton, J., and Elbourne, D. R., 2014. Systematic review of the Hawthorne effect: new concepts are needed to study research participation effects. Journal of Clinical Epistemology, 67: 267-277.

Campbell, R., 1977. Marketing" matching the student to the college. College and University Vol. 52 (4): 591-604.

Catley, P., 2004. Which university? Which Course? Undergraduate students' reflections on the factors that influenced their choices. Brookes eJournal of Learning and Teaching, Vol 1(1). [Online] Available From: http://bejlt.brookes.ac.uk/paper/which-university-which-course-undergraduatestudents-reflections-on-the-factors-that-influenced-their-choices/ [Accessed 05 January 2017]

Ceja, M., 2006. Understanding the role of parents and siblings as information sources in the college choice process of Chicana students. Journal of College Student Development, Vol. 47(1): 87-104

Chapman, D. W., 1981. A model of student choice. Journal of Higher Education Vol. 52(5): 490-505. Art \& Science Group, LLC. 2004. Campus visit drives college choice. StudentPoll 5(5). [Online] Available From: http://www.artsci.com/StudentPOLL/v5n5/printer-friendly.htm [Accessed 16 June 2018]

Clarke, V., and Braun, V., 2013. Teaching thematic analysis: overcoming challenges and developing strategies for effective learning. The Psycologist, Vol. 26(2): 120123.

Cohen, S., 2009. What colleges don't know about admissions. The Chronicle of Higher Education, 56(5): 30.

Dembowski, F. L., 1980. A model for predicting student college choice. College and University, Vol. 55(2): 103-12.

Fischbach, R., 2006. Assessing the impact of university open house activities. College Student Journal, Vol. 40(1): 227-34.

Forbes Lifestyle Magazine. 2007.

Fosu, F. F. and Poku, K., 2014. Exploring the factors that influence students' choice of higher education in Ghana. European Journal of Business and Management, Vol. 6(28): 209-220.

Gasperetti, J. A. 1974. The admissions impact of the campus visit by prospective students. Journal of the National Association of College Admissions Counsellors, Vol. 19(2): 19-20.

Hayes, J. J., 2014. "Increasing enrollment: evaluating college-choice factors at a Midwest Christian university”. Ed.D. Dissertations. 70. [Online] Available From: http://digitalcommons.olivet.edu/edd_diss/70 [Accessed 18 July 2018]

Henry,L. M., 2012.Understanding the college choice process of Catholic Homeschooled students. PhD Dissertation, University of Kansas, USA. [Online] 
Available

From:

https://kuscholarworks.ku.edu/bitstream/handle/1808/10007/Henry_ku_0099D_11

959_DATA_1.pdf;sequence=1 [Accessed 22 October 2017]

Hesel, R.A., 2004. Campus visit drives college choice. StudentPoll 5(5)

Hossler, D., and Gallagher, K.S., 1987. Studying student college choice: a three-phase model and the implications for policymakers. College and University, 62(3): 207221.

Hoyt, J.E., and Brown, A.B., 2003. Identifying college choice factors to successfully market your institution. College and University, Vol. 78(4): 3-10

Javadi, M., and Zarea, M., 2016. Understanding thematic analysis and its pitfalls. Journal of Client Care, Vol. 1(1): 33-39.

Kellaris, J. J. and Kellaris Jr, W. K., 1988. An exploration of the factors influencing students' college choice decision at a small private college. College and University, Vol. 63(2): 187-97

Kim, J. K. and Gasman, M., 2011. In search of a" good college": Decisions and determinations behind Asian American students' college choice. Journal of College Student Development, Vol. 52(6): 706-728

King, K. P., Kobayashi, N., and Bigler, L. G., 1986. Factors influencing students' perceptions of college recruitment activities. College and University, Vol. 61(2): 99-113

Klein, A., 2004. Reinventing the campus tour. University Business, Vol. 7(11): 51-53

Kotler, P., and Murphy, P. E., 1981. Strategic planning for higher education. The Journal of Higher Education, Vol. 52(5): 470-489

Kusumawati, A., Yanamandram,, V. K., and Pereira, N., 2010. University marketing and consumer behaviour concerns: the shifting preference of university selection criteria in Indonesia. Asian Studies Association of Australia $18^{\text {th }}$ Biennial Conference, Adelaide, South Australia, University of Wollongong, Research Online, Centre for Health Service Development, Sydney Business School, P.1-16. [Online] Available

From: https://ro.uow.edu.au/cgi/viewcontent.cgi?referer=https://www.google.com/\&https redir $=1 \&$ article $=1033 \&$ context=chsd [Accessed 20 July 2018]

Lay, R., and Maguire, J., 1981. Modeling the college choice: image and decision. College and University, 56: 113-126.

Magolda, P. M., 2000. The campus tour: Ritual and community in higher education. Anthropology and Education Quarterly, Vol. 31(1): 24-46.

Maller, C., Townsend, M., Pryor, A., Brown, P., and Leger, M. S .T., 2005. Healthy nature healthy people: 'contact with nature' as an upstream health promotion intervention for populations. Health Promotion International, Vol. 21(1): 45-53.

Ming, J. S. K., 2010. Institutional factors influencing students' college choice decision in Malaysia. A conceptual framework. International Journal of Business and Social Science, Vol. 1(3): 53-58 
Murphy, P., 1981. Consumer buying roles in college choice: parents and students' perceptions. College and University, Vol. 56(2): 140-150.

Noel-Levitz, 2009. Student recruitment practices and strategies at four-year and twoyear institutions. [Online] Available From: https://www.ruffalonl.com/documents/shared/Papers_and_Research/2009/Student RecruitmentPracticesandStrategies09.pdf [Accessed 5 October 2018]

Nowell, L. S., Norris, J. M., White, D. E., and Moules, N. J., 2017. Thematic analysis: striving to meet the trustworthiness criteria. International Journal of Qualitative Methods, Vol. 16(1): 1-13.

Okerson, J. R., 2016. "Beyond the campus tour: college choice and the campus visit". Dissertations, Theses, and Masters projects. Paper 1463413085. [Online] Available From: http://dx.doi.org/10.21220/W43W20 [Accessed 01 August 2018].

Pampaloni, A. M., 2010. The influence of organizational image on college selection: what students seek in institutions of higher education. Journal of Marketing for Higher Education, Vol. 20(1): 19-48

Pimpa, N., 2005. A family affair: the effect of family on Thai students' choices of international education. Higher Education: the International Journal of Higher Education and Educational Planning, Vol. 49(4): 431-448

Robertson, J. T., Hurst, T., Williams, K., and Kieth, L., 2017. "The potential return on investment of the recruitment strategies for an academic unit focused on agricultural sciences". Journal of Applied Communications, 101 (2). [On line] Available From: http://doi.org/10.4148/1051-0834.1005 [Accessed 14 August 2018]

Sevier, R. A., 1992. Recruiting African-American undergraduates: a national survey of the factors influencing institutional choice. College and University, 68: 48-51

Sevier, R. A., 2000. Building an effective recruiting funnel. Journal of College Admission, 169: 10-19

Shanka, T., Quintal, V., and Taylor, R., 2005. Factors influencing international students' choice of an educational destination-A correspondence analysis. Journal of Marketing for Higher Education, Vol. 15(2): 31-46

Spoon, A. N., 2006. Identifying concepts that influence high school students during college Tour. Master of education thesis, Graduate College of Bowling, Green State University. [Online] Available From: https://etd.ohiolink.edu/!etd.send_file?accession=bgsu1143484472\&disposition=in line [Accessed 18 December 2017]

The Chronicle of Higher Education, 2009. Massachusetts. [Online] Available From: https://www.chronicle.com/article/Massachusetts-Almanac-2009/48120/ [Accessed 10 November 2017]

University of Colorado at Colorado Springs, 2006. Campus design guidelines. [Online] Available

From: https://www.uccs.edu/Documents/facsrvs/campus\%20design\%20guidelines\%2007. pdf [Accessed 21 January 2018] 
Veloutsou, C., Lewis, J. W., and Paton, R. A., 2004. University selection: information requirements and importance. The International Journal of Educational Management, Vol. 18(3): 160-171.

Wickström, G. and Bendix, T., 2000. The "Hawthorne effect"—what did the original Hawthorne studies actually show? Scandinavian Journal of Work, Environment and Health, pp.363-367.

Yost, M., Jr, Tucker, S. L., 1995. Tangible evidence in marketing a service: The value of a campus visit in choosing a college. Journal of Marketing for Higher Education, Vol. 6(1): 47-67.

Zain, O. M., Jan, M. T., and Ibrahim, A. B., 2013. Factors influencing students' decisions in choosing private institutions of higher education in Malaysia: a structural equation modelling approach. Asian Academy of Management Journal, Vol. 18(1): 75-90

\section{Author Biography}

Laura Ariko Otaala (PhD) is an Associate Professor in the Institute of Languages and Communication Studies at Uganda Martyrs University. She holds a $\mathrm{PhD}$ in Language and Higher Education. She does research in sociolinguistics, teaching methods and learning environments. 